\title{
Avaliação da Ação Bactericida do Ácido Acético e Cloro em Alface (Lactuca Sativa) Convencional
}

\section{Diane Cássia Sebben (I), Giovanna Cavagnari (I), Wilma Spinosa (I)}

(I) UEL - Universidade Estadual de Londrina ( Rodovia Celso Garcia Cid, Km 380 - Campus Universitário, Londrina - PR, 86057-9)

\section{Resumo}

INTRODUÇÃO Os vegetais são alimentos importantes e fornecem nutrientes essenciais que trazem benefícios à saúde. A ingestão de hortaliças cruas pode transmitir doenças infecciosas e foram responsáveis por 12,5\% dos surtos ocorridos no Brasil entre 2000 e 2011 (BRASIL, 2011). Usualmente consumidas cruas o processo de higienização é o único tratamento recebido entre cultivo e consumo. Se a lavagem e sanificação forem conduzidos de forma inadequada poderá ocorrer transmissão de doenças. Procedimentos eficientes de desinfecção são necessários para obtenção de hortaliças inócuas. O trabalho teve como objetivo avaliar a ação bactericida do ácido acético (concentração 50\%) e de solução de hipoclorito de sódio (concentração $0,96 \%$ cloro) em alface (Lactuca sativa) submetida a contaminação com E. coli. MATERIAIS E MÉTODOS Amostras de alface foram adquiridas em mercado de Londrina-PR e submetidas a contaminação com cepas de E. coli. Para desinfecção diluiuse $6 \mathrm{ml}$ de solução à base de cloro em $1 \mathrm{~L}$ de água por $15 \mathrm{~min}$ e $200 \mathrm{ml}$ de ácido acético em $1 \mathrm{~L}$ de água por $10 \mathrm{~min}$, em $250 \mathrm{~g}$ da amostra contaminada. Após foi realizado a contagem de Coliformes Totais, $45^{\circ} \mathrm{C}$ e E. coli. RESULTADOS E DISCUSSÃO As análises foram realizadas em amostras controle (sem desinfeção) e tratadas com cloro e ácido acético, nas diluições -1, -2 e -3. Nos resultados obtidos para desinfeção com cloro, duas amostras da diluição $10-^{3}$ não apresentaram contaminação. $\mathrm{Na}$ desinfecção com ácido acético uma amostra da diluição $10-^{1}$, duas amostras da diluição $10-^{2}$ e três amostras da diluição $10-^{3}$ não apresentaram 
contaminação. Observou-se que a contaminação foi efetiva e que o ácido acético teve melhor ação sobre as amostras contaminadas. Os valores mais prováveis (NMP) de coliformes $45^{\circ}$ foram calculados e encontrou-se 2.400 $\mathrm{NMP} / \mathrm{ml}$ na amostra controle, $460 \mathrm{NMP} / \mathrm{ml}$ na amostra sanitizadas com cloro e $15 \mathrm{NMP} / \mathrm{ml}$ na amostra sanitizada com ácido acético. Os testes bioquímicos mostraram resultados positivos para E. coli. CONCLUSÃO Constatou-se que o ácido acético demonstrou um melhor efeito sobre as amostras de alface contaminada. Já o tempo de imersão para desinfecção não foi adequado, pois as alfaces foram afetadas em sua aparência. Novos testes devem ser conduzidos com diferentes concentrações e tempos de imersão para a desinfecção de alfaces.

Palavras-Chave: bactericida, cloro, ácido acético, alface Agência de Fomento: 